\title{
An Analysis of Macroeconomic Determinants of Remittances in Southern Africa
}

\author{
Fwasa K Singogo, Emmanuel Ziramba \\ Department of Economics, University of Namibia, Windhoek, Namibia \\ sfwasabk@yahoo.com, eziramba@unam.na
}

\begin{abstract}
The study analyzed macroeconomic determinants of remittances in Southern Africa and used annual data for the period ranging from 2003-2016. The macroeconomic determinants used include: remittances themselves, inflation rate, GDP growth rate, nominal exchange rate, broad money and age dependency ratio. A panel study was carried out using both the fixed and random methods of which the random method was found to be most appropriate. The countries included in the study were Botswana, Lesotho, Malawi, Mozambique, South Africa, Swaziland and Zambia. It was found that of the variables used, only changes/improvements in the home countries' economic environment and the exchange rate were statistically significant.
\end{abstract}

Keywords: Remittances, Macroeconomic Determinants, Southern Africa.

\section{Introduction and Background}

Remittances otherwise coined as "Personal remittances" by the World Bank are defined as the sum of personal transfers and compensation of employees to their respective home countries. As such, the discussion around remittances is centered more on migrants who find themselves in "favourable situations". Remittances as is illustrated in Figure 1 have been on the rise globally. According to the World Bank (2016), they were estimated to be approximately U.S. $\$ 601$ billion with U.S. $\$ 441$ billion expected to be received by developing countries.

Figure 1: Global Remittances and Other Inflows (1990-2016)

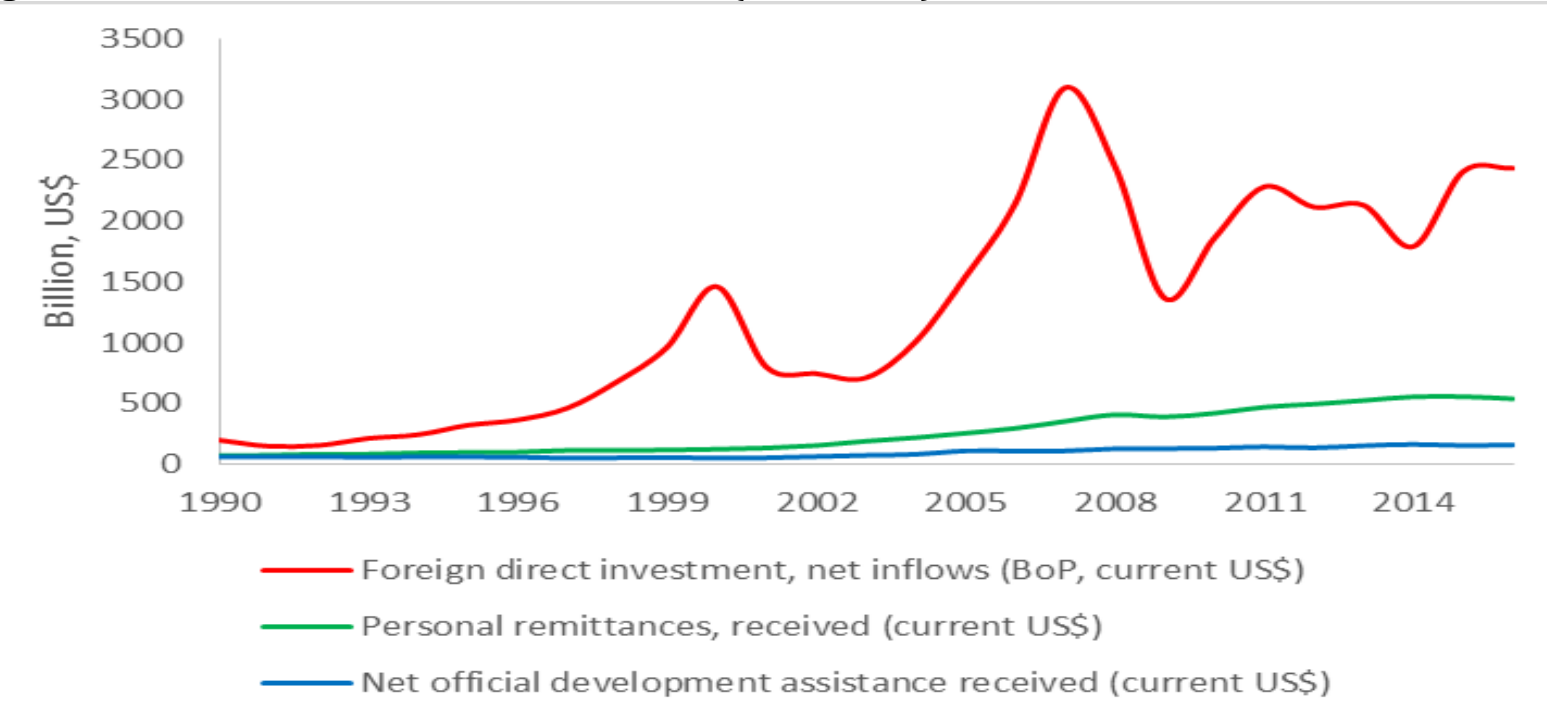

Source: Authors compilation of WDI

As illustrated in Figure 1, global remittances surpass global Official Development Assistance/Aid, as literature purports (Tabit \& Moussir, 2016) and are generally more stable in comparison to FDIs (Ratha \& Plaza, 2011; Boly, Coniglio, Prota, \& Seric, 2014). However, in the Southern African region, remittance inflows fall below ODA as illustrated in Figure 2a below. This trend should however, not be looked at on face value but rather the informality of remittance transfer and poor data collection (which also led to the omission of several countries that would have been part of the study but were not due to a lack of data) on the continent should be considered (Mohapatra \& Ratha, 2011). 
Figure 2: (a, b) (a) Remittances and Other Inflows for - Select Southern African Countries (19902016). (b) Personal Remittances, Received (current US\$) - for Select Southern African Countries (2003-2016)
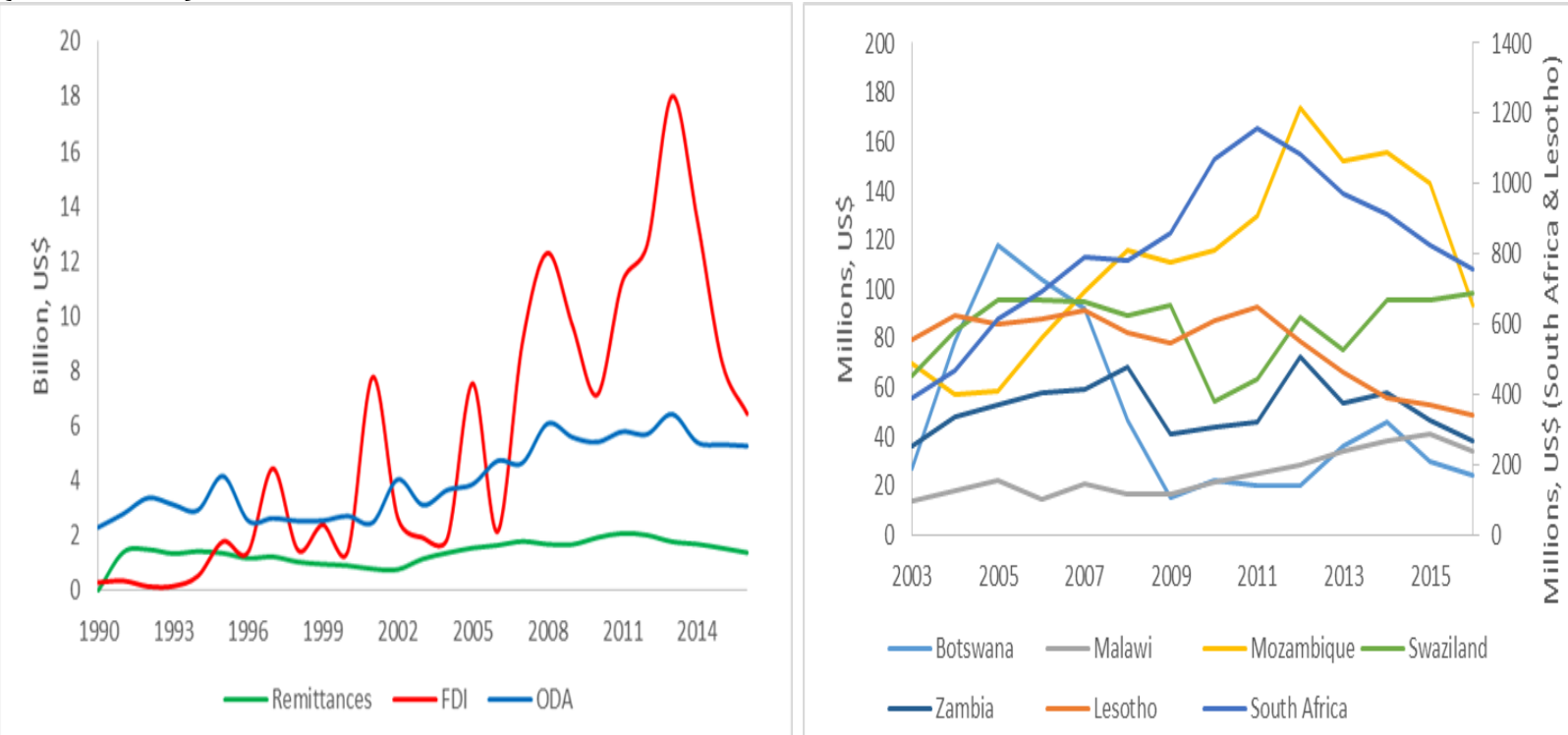

Source: Authors compilation of WDI

The stability of remittance inflows further substantiates calls for countries in the region to consider it as a development source of revenue, more so given the less straining conditions associated with them in comparison to the other sources (FDI and ODA). However, as can be observed in figure $2 \mathrm{~b}$, individual countries do not depict the same stability. Overtime however, the trend has generally been constant in southern African. A point of interest is the disparity of remittance inflows by each nation, particularly in South Africa and Lesotho. Both countries have considerably higher remittance inflows recorded (probably highlighting their better records of data in comparison to the other nations). Another point of interest is the post-recession behavior of the remittance inflows. It is noticed that in both the Figure $2 \mathrm{~b}$ and 3 , that there were slight increases in remittance inflows before declines. The behavior of remittance inflows noticed around the recession period adds to their novelty as an alternative source of funds to spur development and growth in Southern Africa.

Figure 3: Remittance Inflows (\% of GDP) - for Select Southern African Countries (2003-2016)

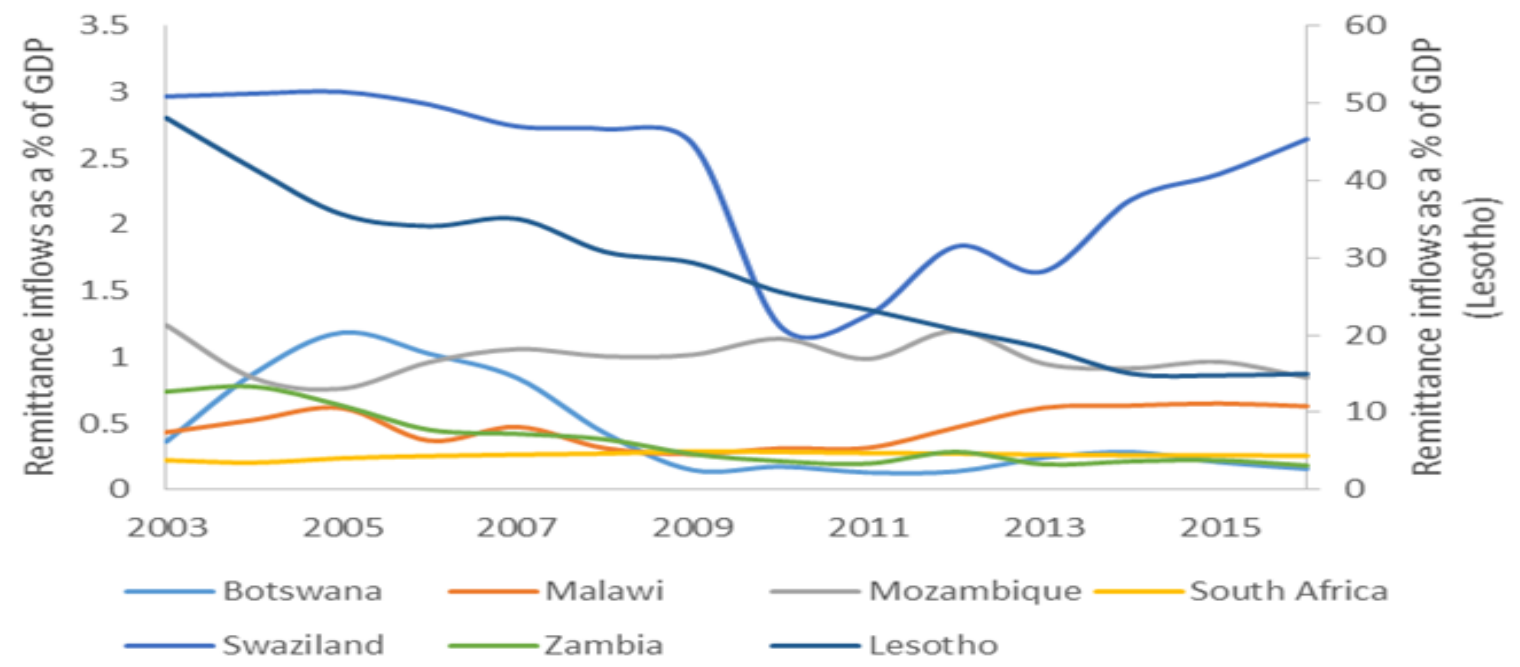

Source: Authors compilation of WDI 
As is illustrated in Figure 3, remittance inflows for some of the select countries make up a considerable amount of GDP - more so as illustrated by Lesotho especially as it has been rising, post 2010. However, this is not the case for the majority of the countries. Even so, the magnitude cannot be ignored. The constant percentage, though in some cases as is the case with Swaziland where remittances are in decline, should be taken with caution as official estimates are prone to be understated more so given the informal transfer of remittances in the region (Mohapatra \& Ratha, 2011). According to Boly, Coniglio, Prota and Seric (2014), about $50 \%$ of the African diaspora is located within the continent; and particularly, intra-regional migration accounts for almost 65\% of total emigrants in Sub-Saharan Africa. Southern Africa the focus area of this study is a relatively integrated trade block. Migration in Southern Africa occurs for various reasons these being conflict, political instability and economic instability to mention but a few. In the region, migration is driven more by economic instability now than that of political or conflict reasons (Eyden, Sekyere, \& Kemegue, 2011), with countries like Zimbabwe, Mozambique and Angola being examples. Southern Africa is further characterized by high unemployment levels, poverty, low financial inclusion and generally low standards of living. According to Porter (2017), it was estimated that nearly 88 million people live in extreme poverty in the region.

With the region accounting for $9 \%$ of extreme poverty globally, although it only makes up $2.5 \%$ of the world's population furthermore, the region has some of the highest costs of sending remittances, for example in the third quarter of 2015 , it cost about $19 \%$ of U.S. $\$ 200$ to send remittances from South Africa to Zambia and $17.4 \%$ from South Africa to Botswana. Whereas, in comparison to other developing countries out of Africa, it cost 6.70\% from Brazil to Bolivia and 4.4\% from Chile to Peru (Watkins \& Quattri, 2014; World Bank, 2016). Recently there has been a shift of thought from the perception of emigration being a loss to that of gains (Ratha \& Plaza, 2011), particularly of remittances and knowledge through exposure. Considering their magnitude and uniqueness (it is a source of income rivaling and with close to no conditions in comparison to other sources for example FDI and ODA), it is believed that even without targeted (macro) programs they have been able to alleviate at least household issues (Crush \& Frayne, 2007; Dorantes, 2014; Tabit \& Moussir, 2016). Therefore, their absence could be detrimental to the region, which is not helped by the hostile environment surrounding migration and foreigners in the region. Therefore, remittances are an interesting avenue of focus that if channeled appropriately has the potential to alleviate a majority of the aforementioned issues regardless of its size in comparison to other regions.

\section{Literature Review}

As mentioned earlier, the paper focuses on macroeconomic determinants. The macroeconomic approach considers macroeconomic variables of the sending, as well as receiving countries. In this case, researchers have used aggregate data that affects the behavior of remitting such as the economic situation, interest rates, exchange rates, wage rates, inflation, etc. While the remitting decision is made at the micro level: it is at the macro level where how much is remitted, is further determined. There are a number of studies that have examined not only macroeconomic determinants of remittances but economic determinants in general. These studies focus on issues like what social-economic factors might cause migrants to remit and once they do remit, what factors affect the amount is remitted home. However, empirical studies on the phenomenon of interest in Southern Africa particularly are minimal with most studies in Africa either being on Sub-Saharan Africa, or SADC - which encompasses various countries that may not be a true reflection of what happens in Southern Africa, and other sub regions on the continent.

The findings have been found to vary as has the impact of factors that affect the amounts remitted. Among the various determinants (income, education, exchange rates and dependency just to mention a few), education has been found to be one of the important determinants of remittances not only because of the perceived amounts the educated verses the uneducated remit (which has been debated) but that remittances are sent to foster education. Two studies (Faini, 2007; Adams, 2008) used cross-country data from a variety of developing countries and found that skilled migrants (otherwise known as educated migrants) remit less than unskilled migrants. This they perceived to be down to a number of skilled migrants spending a lot of their time abroad and therefore moving with their families and having no reason to remit as much as unskilled migrants. These findings were however contested by Bollard, McKenzie, Morten, and Rapoport (2009), who used micro data from immigrant surveys in 11 OECD countries and found. 
While education has a mixed effect on the disposition to remit as aforementioned, there are several determinants. Most linked to one another as is the case with education and dependency. Just as the determinants vary, so too do the methods of measurement Huang and Vargas-Silva (2006), using a VECM; Baldé (2009), using a Two Stage Least Square (TSLS); whereas, Coulibaly (2009) used a panel VAR) among other issues. Baldé (2009) found that remittances do not have a direct positive impact on growth. Whereas, Huang and Vargas-Silva (2006) and Coulibaly (2009) found supporting results: in which both studies concluded that economic conditions in the host country are more significant and that remittances respond more to them than to the economic conditions in the home countries. This was irrespective of different time periods of study and countries included, although both studies looked at a similar region (Latin American countries). In another study, related to macroeconomic determinants of remittances, Yuni, Omeje and Asogwa (2013) also investigated the phenomenon in 21 selected African countries for the period 1980 to 2011. The variables used included remittances received, real exchange rate, broad money base, tax revenue and the inflation rate. Applying a dynamic generalized method of moments (GMM), they found that the broad money base (M2) and tax revenue had a statistically significant but negative relationship with remittances, whereas, the inflation rate as well as age dependency ratio were statistically significant with respective positive relationships.

Lim and Mahbub-Morshed (2015), in keeping with macroeconomic determinants of remittances, investigated the aforementioned for 122 developing countries for the period ranging from 1990 to 2010. Their study applied ordinary least square (OLS) - fixed effects (FE), and random effects (RE) - on the variables: Migrant stock, GDP per capita and private credit to GDP. The analysis showed that home income stock had a negative impact on remittances, suggesting an increase in remittances could have been due to a decrease in home income. Their results showed a significant impact of financial development in easing the flow of remittances to developing countries. In a study examining macroeconomic determinants of remittances for the period ranging from 1990 to 2014, Zakari and Nasiru (2016), looked at 14 West African countries. Their variables of interest included: Remittances measured as total personal remittances received in US dollars; Home income was proxied by gross domestic product measured as constant 2005 US dollars; the labour market situation proxied by the unemployment rate; and the real exchange rate as a proxy for the exchange rate. The study applied several panel unit root tests, then the Pedroni cointegration test before a fully modified ordinary least square (FMOLS) estimation. It was found that there existed a long run relationship among the variables. The FMOLS revealed that home income and the exchange rate had a positive and significant impact on remittance inflows. It was however found that the labor market situation exhibited the opposite. Their findings led them to the conclusion that, remittance inflows increased in response to the increases in home income.

\section{Methodology}

This study employed a quantitative method and uses data that covers a panel of 7 countries to analyze macroeconomic determinants of remittances in select Southern African countries. The study used secondary, annual data ranging from 2003 to 2016. The data used was extracted from the World Bank Development Indicators (WDI) and the International Financial Statistics (International Monetary Fund - IMF). The Southern African countries selected were: Botswana, Lesotho, Malawi, Mozambique, South Africa, Swaziland and Zambia. As discussed in the literature, remittance determinants fall into two categories. These being micro and macroeconomic determinants in keeping with the focus of this study, macroeconomic analysis were undertaken and the modeling approach used by Yuni, Omeje, and Asogwa (2013) is adopted. The initial model specification is given as:

$$
R E M_{i t}=\beta_{0}+R E M_{i t-1}+I N F_{i t}+G D P G_{i t}+E X C_{i t}+B M_{i t}+A G E D_{i t}+u_{i t}+\varepsilon_{i t}
$$

The model uses remittances of the previous year $\left(R E M_{i t-1}\right)$, the inflation rate $\left(I N F_{i t}\right)$, the GDP growth rate $\left(G D P G_{i t}\right)$, the nominal exchange rate $\left(E X C_{i t}\right)$, and broad money variable $\left(B M_{i t}\right)$, and age dependency ratio $\left(A G E D_{i t}\right)$ as the macroeconomic determinants. Whereas; $u_{i t} \sim i i d\left(0, \sigma_{u}^{2}\right)$ is the unobserved random effect that varies across countries but not over time, and $\varepsilon_{i t} \sim i i d\left(0, \sigma_{\varepsilon}^{2}\right)$ is an idiosyncratic error term, $i=1, N ; t=1, T$. Remittances are the dependent variable represented by Personal remittances, received (\% of GDP). As per theoretic and literature consideration Lagged Remittances are used as one of the dependent variables to explain current remittances (Coulibaly, 2009; Yuni, Omeje \& Asogwa, 2013). For the inflation variable, inflation as the GDP deflator (annual \%) is used. This was done to capture the economic environmental conditions of the home countries as opposed. 
Coulibaly (2009) who used GDP per capita as the study felt inflation is more reflective of the aforementioned whereas, to show changes in the economic environment in the home countries, the study used the GDP growth (annual \%) variable as opposed to Coulibaly's study that used Real GDP. Other control variables of importance that were used include: the Nominal exchange rate (National Currency per US Dollar, End of Period), Broad money as \% of GDP and the Age dependency ratio which was reflected by Age dependency ratio (\% of working-age population). The exchange rate is representative of the cost of send remittances from one country to another. Whereas, broad money was used to represent market sophistication (as done by Yuni, Omeje \& Asogwa, 2013; whereas Eyden, Sekyere \& Kemegue, 2011 used money and quasi money as a percentage of GDP to represent market sophistication). This was done so that a single regression analysis would be enough to see the effect of market sophistication in the region which is apparent as is illustrated by the differences between economies as those in Botswana. Even more so by South Africa in comparison with countries like Malawi, Mozambique, Lesotho, Swaziland and Zambia last but not least, the Age dependency ratio was used to analyze how dependency on remittances affect remittance flows in the region. Aside from the analysis from the above econometric model, this paper made use of impulse response functions and variance decompositions. The impulse response functions were used to determine the effects of one standard deviation in one variable on the other variables in a system. Whereas, the variance decompositions show how shocks reverberate through a system and measure the relative importance of each innovation that affect the respective variables.

\section{Empirical Results and Discussion}

The data was first converted to log form to eliminate extreme variability in the variables. This was done for all the variables except for GDP growth which was already converted. In keeping with the outlined methodology, the unit root tests were the first to be estimated. This was done in order to avoid spurious results down the line. As aforementioned, the study checked the stationarity properties using the Im, Pesaran and Shin Test, the ADF-Fisher Chi-square test, the PP-Fisher Chi-square and last but not least the Levin, Lin and Chu test. It was found from the unit root tests that all the variables apart from age dependency (LNAGED) become stationary at first difference at $5 \%$ level of significance and are therefore of order of integration one. As aforementioned, LNAGED was the only variable that did not become stationary at first difference but rather at second difference and is therefore of order of integration two.

Diagnostic Tests: Having applied the unit root tests, stability tests were applied to check the stability of the variables to be used in the model. The AR roots check was one test derived for this. It was found that all the dots (roots) fell within the circle and it was therefore safe to conclude that the variables to be used in the model were stable or satisfy the stability condition. After which the Residual Serial Correlation LM test was estimated as one of the diagnostic tests to ensure the validity of the overall model to be estimated. Of which it was found that all the $\mathrm{p}$ values were greater than $\alpha$ at all levels of significance (1\%, 5\% and $10 \%)$. This leads to the conclusion of no serial correlation and that suitable estimates could be made as the null hypothesis cannot be rejected.

Panel Cointegration Test: Having applied the unit root tests and diagnostic tests, the study then applied the Pedroni panel cointegration test to see if there existed a long run relationship or otherwise. The results are presented in the table below.

Table 1: Panel Cointegration Tests Within-Dimension

\begin{tabular}{lllll}
\hline & Statistic & p-value & $\begin{array}{l}\text { Weighted } \\
\text { Statistic }\end{array}$ & p-value \\
\hline Panel v test & -0.403 & 0.656 & -1.462 & 0.928 \\
Panel rho test & 1.424 & 0.923 & 0.970 & 0.834 \\
Panel PP test & -2.603 & 0.005 & -5.295 & 0.000 \\
Panel ADF test & 3.066 & 0.999 & 0.019 & 0.508 \\
Between-dimension & & & & \\
& Statistic & & p-value & \\
Group rho test & 2.165 & & 0.985 & \\
\hline
\end{tabular}




\begin{tabular}{lll}
\hline Group PP test & -6.135 & 0.000 \\
Group ADF test & 0.091 & 0.536 \\
\hline
\end{tabular}

Source: Authors' computations

As presented above, of the eleven tests done, eight could not reject the null hypothesis of no cointegration as the $\mathrm{p}$ values were greater than $\alpha(1 \%, 5 \%$ and $10 \%$ level of significance). This was the case for six of the tests from the within dimension and two of the tests from the between dimension tests. As a majority of the tests could not reject the null hypothesis, the study concluded that there was no cointegration and therefore, there was no long run relationship or association between the variables. After the cointegration test was applied, both the fixed and random effects model was estimated. After which, the Hausman test was applied to pick which of the two aforementioned tests would be appropriate to use. The result of the Hausman test is depicted in the table below.

Table 2: The Hauman Test

\begin{tabular}{llll}
\hline Test Summary & Chi-Sq. Statistic & Chi-Sq. d.f. & Prob. \\
\hline Cross-section random & & 6 & 0.155 \\
\hline
\end{tabular}

Source: Authors' computations

The Hausman test has the null hypothesis that the random effect estimator is correct. As the $\mathrm{p}$ value is greater than $\alpha(1 \%, 5 \%$ and $10 \%$ level of significance), the study could not reject the null hypothesis of no statistical significance. The Random effect estimators were therefore chosen and are the ones from which inferences were made.

Estimation Results: As the random effect estimators were the ones chosen over the fixed effect as per the Hausman test, the model generated was that of the random effect estimators and provided the following:

Table 3: Estimation Results

\begin{tabular}{llll}
\hline Variable & Std. error & T stat & Prob. \\
\hline C & 0.029 & -2.763 & 0.007 \\
D(LNREM(-1)) & 0.094 & 1.620 & 0.109 \\
D(LNINF) & 0.022 & -0.375 & 0.709 \\
D(GDPG) & 0.008 & 3.300 & 0.002 \\
D(LNEXC) & 0.160 & 2.517 & 0.014 \\
D(LNBM) & 0.273 & 0.273 & 0.786 \\
D(LNAGED, 2) & 11.265 & -0.756 & 0.452 \\
& & & \\
$\mathbf{R}^{2}$ & 0.185 & Prob (f statistic) & 0.015 \\
Adjusted R & 0.120 & F statistic & 2.833 \\
& & D Watson & 2.312 \\
\hline
\end{tabular}

Source: Authors' computations

From the estimation results, the only significant variables were GDP growth and the exchange rate which represented changes/improvements in the home countries economic environment and costs of remitting respectively as their $\mathrm{p}$ values were less than $\alpha(1 \%, 5 \%$ and $10 \%$ level of significance and $5 \%$ and $10 \%$ level of significance respectively). This is in contradiction with the finding of Yuni, Omeje and Asogwa (2013), who found the exchange rate to be insignificant. The finding of the economic environmental conditions being insignificant is similar to that of Coulibaly (2009). However, the finding of market sophistication being insignificant is different from that of Yuni, Omeje and Asogwa. It should however, be mentioned that Eyden, Sekyere and Kemegue, (2011) found different results in regards to market sophistication in their one study. While certain methodology said it was significant, another said otherwise. Furthermore, while Coulibaly; Yuni, Omeje and Asogwa; and Eyden, Sekyere and Kemegue found that remittances from the previous period are significant in affecting current remittance flows, the results of the study show otherwise. 
The results of the study imply that the economic environmental conditions and market sophistication do not influence the receiving of remittances in the select Southern African countries. These findings were not expected as it would be expected that a poor economic environment (which one would argue has been prevalent in the region) would see remittances flow into the economy as migrants try to support those left behind (of course this is also dependent on the fact that migrants left family behind) and otherwise. However, as changes/improvements in the economic environment is significant, the economic environment of the home country relative to the host country could play a vital role in the home countries as the changes reflect to an extent the economic environment. Autocorrelation was not found to be an issue in the residual given the $\mathrm{d}$ Watson at 2.312 (approximately equal to 2). The model was found to be jointly statistically significant as the probability (statistic test) is at 0.015 and the F statistic is at 2.833. However, as the probability (statistic test) is at 0.015 it is worth noting that there may be issues with the fitting of data (i.e., the independent variables are not purely random with respect to the dependent variable). Generally, the $\mathrm{R}^{2}$ is low in cross sectional data as compared to time series data. In panel data due to heterogeneity of cross sections, it is not too high.

Which is to an extent expected given the set objectives the $\mathrm{R}^{2}$ at 0.185 and the adjusted $\mathrm{R}^{2}=0.120$ are relatively low, indicating that the model does very little in explaining of the variability of the response of the data around its mean. Regardless of the low $\mathrm{R}^{2}$, the results can be interpreted and relied upon as in panel data analysis; the individual significance and overall significance of the model instead of the R square or adjusted $\mathrm{R}$ square are relied on. All the significant variables were found to have a positive relationship with the dependent variable implying remittances would increase by respective percentage changes given a percentage change from the respective dependent variables. After the model estimation, one more diagnostic test was applied to see if the aforementioned issues from the estimation results would be problematic (multicollinearity and the positive autocorrelation). This being the Residual cross-section dependency test of which the null hypothesis of the test is that there is no cross-section dependence (correlation) in residuals and the decision rule being that that if the $\mathrm{p}$ value is greater than $\alpha(1 \%, 5 \%$ and $10 \%$ level of significance), the null hypothesis cannot be rejected which was the case. Therefore, the study concluded that the estimates found were valid and suitable to make inferences from.

Impulse Response Functions: In keeping with the outlined procedure, after the model estimation the impulse responses of remittances were derived. The figures below illustrate the responses of remittances from the respective independent variables.

Figure 4: Impulse Responses Response to Cholesky One S.D. Innovations

Response of LNREM to LNREM

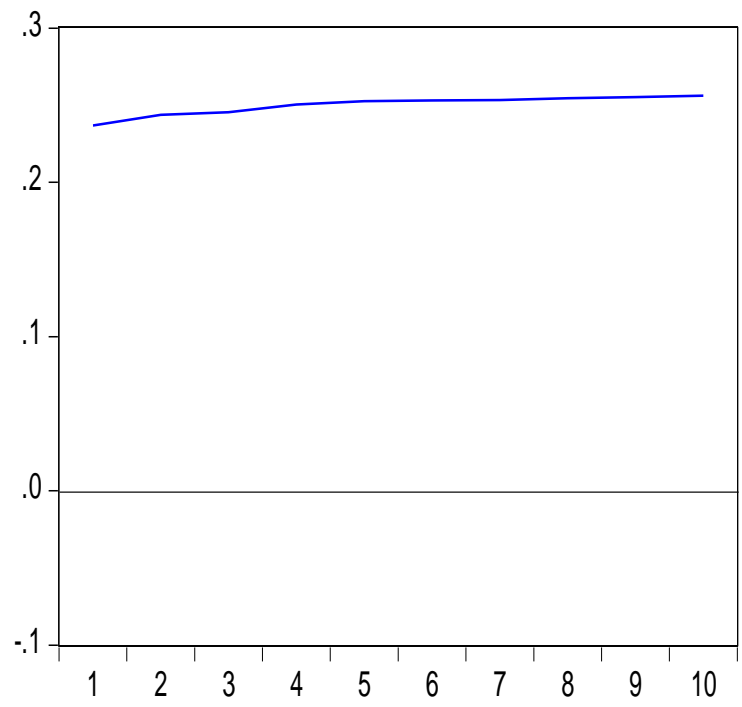

Response to Cholesky One S.D. Innovations

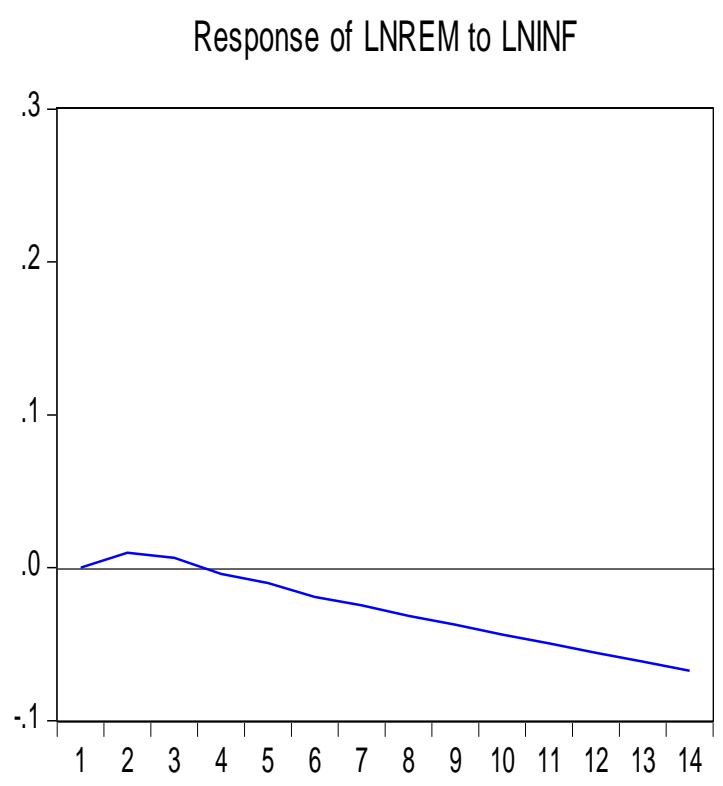


Response of LNREM to GDPG

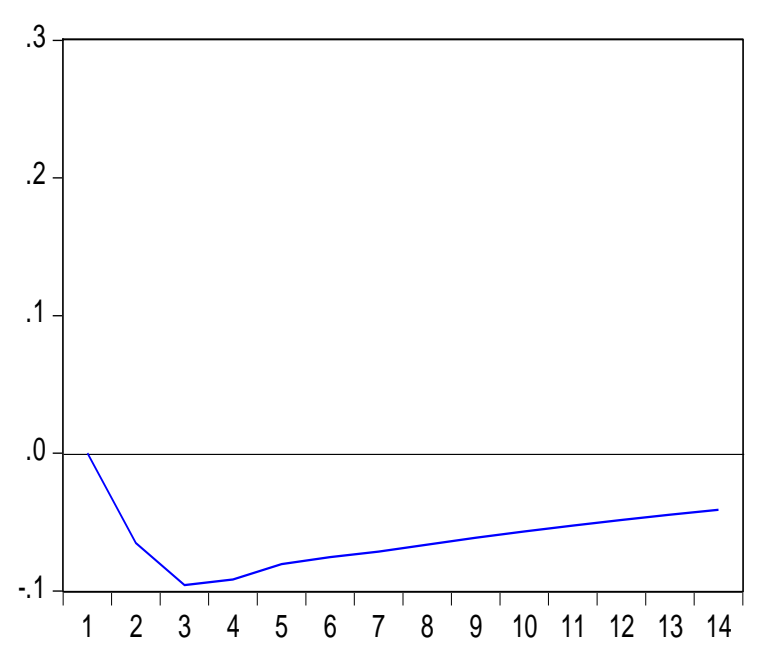

Response to Cholesky One S.D. Innovations

Response of LNREM to LNBM

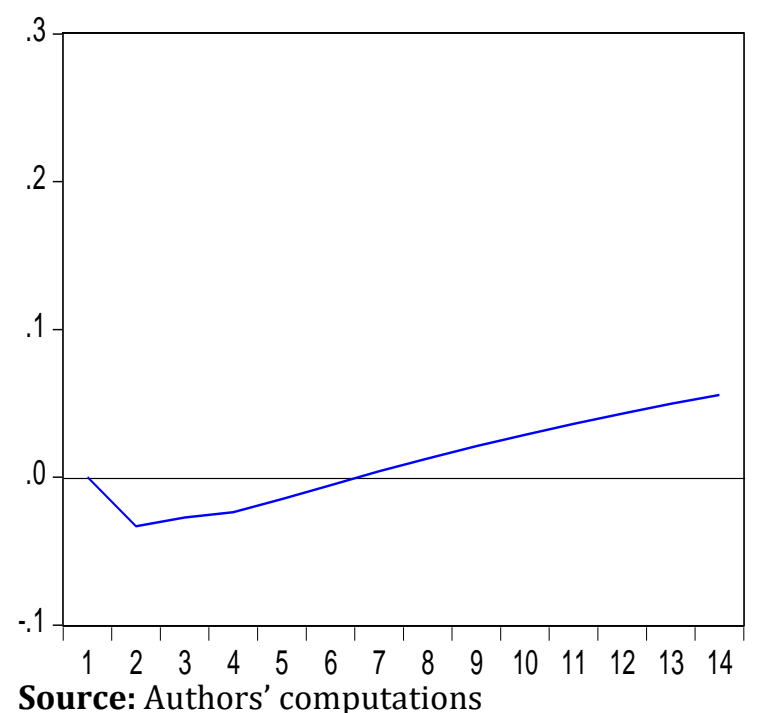

Response of LNREM to LNEXC

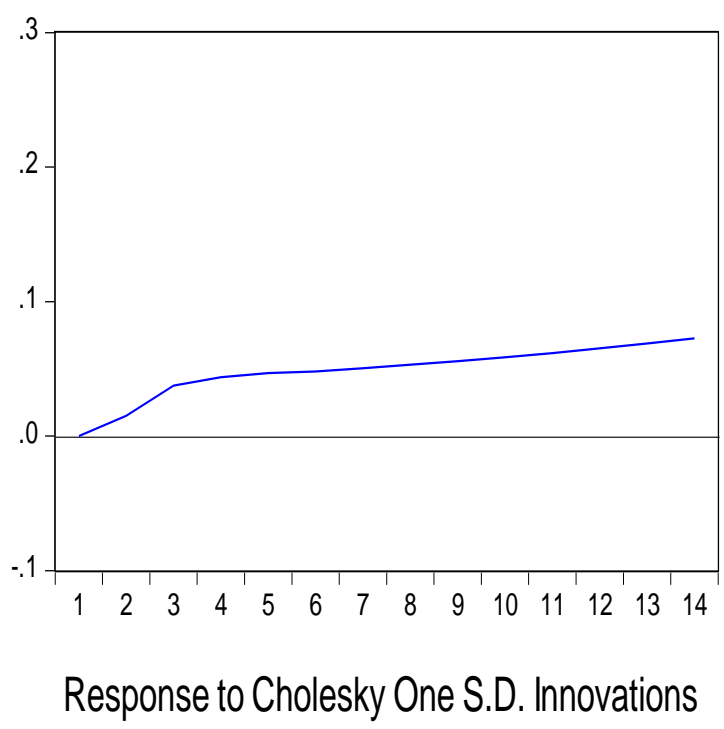

Response of LNREM to LNAGED

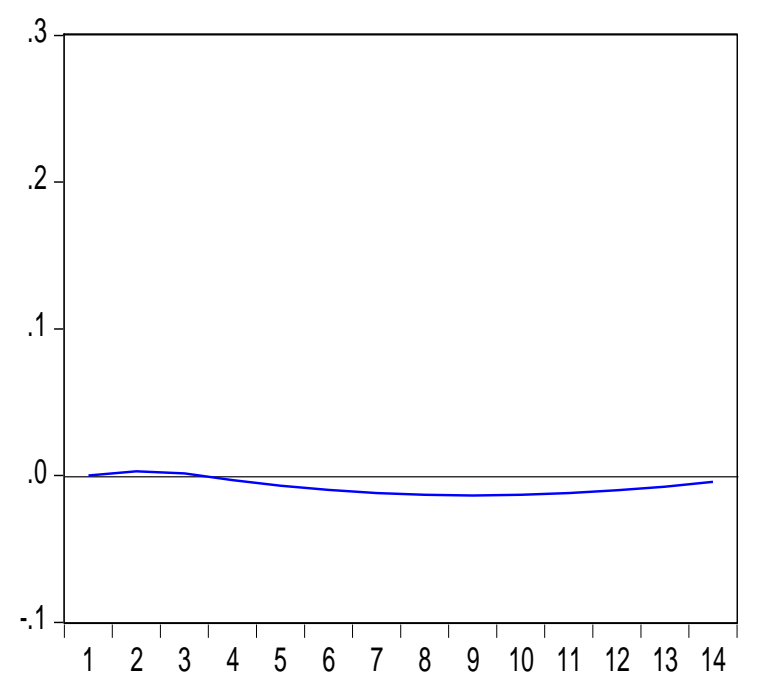

As illustrated, a one standard deviation or shock from remittances themselves sees a slight positive response in remittance inflows. However, over time this response does not vary but remains relatively constant. On the other hand, a one standard deviation or shock from inflation (economic environmental environment) to remittance inflows would initially see a positive response in remittance inflows. However, over time (over three years) remittance inflows would see a fall as a response to a shock in the economic environmental conditions. In regards to remittance inflows response to changes/improvements in the economic environment (GDPG), a standard deviation or shock in the economic environment would see a fall (negative response) in remittance in flows. Over time, remittance in flows would increase but not be 'substantial'. Remittance inflows respond favorably to shocks in the exchange rate as is expected. Given that the exchange rate is in U.S. dollar (for consistency among the countries), a shock in terms of a depreciation of the local currencies would indeed result in perceived and actual increases in remittance inflows. 
In regard to remittance inflows response to the market sophistication, it is noticed that a shock initially results in a negative response before a positive response six years later. From the above, it can be inferred that the more market sophistication, the more remittance inflows are initially likely to be hampered before migrants or individuals get used to the systems in place. Last but not least, remittance inflows respond slightly positively to shocks in dependency. However, as time goes by the response is negative though it does improve slightly over time. This could be attributed to the motives of which migrants are remitting. It could be assumed that initially migrants do remit funds home but as to whether their families join them or they get burdened by dependents back home verses their needs in foreign lands that see a fall and negative response to remittance inflows is not clear.

Variance Decomposition Test: The variance decompositions were then applied and showed how shocks reverberated through a system and measure the relative importance of innovation effects on respective variables.

Table 4: Variance Decompositions of Remittance Percentage of the Variation in Remittances Explained by:

\begin{tabular}{llllllll}
\hline Period & S.E. & LNREM & LNINF & GDPG & LNEXC & LNBM & LNAGED \\
\hline $\mathbf{1}$ & 0.237 & 100.000 & 0.000 & 0.000 & 0.000 & 0.000 & 0.000 \\
$\mathbf{2}$ & 0.348 & 95.316 & 0.078 & 3.503 & 0.188 & 0.909 & 0.007 \\
$\mathbf{3}$ & 0.439 & 91.155 & 0.071 & 6.969 & 0.847 & 0.954 & 0.005 \\
$\mathbf{4}$ & 0.516 & 89.497 & 0.057 & 8.207 & 1.329 & 0.902 & 0.007 \\
$\mathbf{5}$ & 0.583 & 89.077 & 0.075 & 8.362 & 1.695 & 0.773 & 0.020 \\
$\mathbf{6}$ & 0.642 & 88.942 & 0.150 & 8.271 & 1.953 & 0.644 & 0.040 \\
$\mathbf{7}$ & 0.696 & 88.860 & 0.252 & 8.088 & 2.186 & 0.551 & 0.063 \\
$\mathbf{8}$ & 0.747 & 88.789 & 0.397 & 7.818 & 2.403 & 0.507 & 0.086 \\
$\mathbf{9}$ & 0.795 & 88.697 & 0.571 & 7.498 & 2.613 & 0.517 & 0.104 \\
$\mathbf{1 0}$ & 0.841 & 88.545 & 0.780 & 7.158 & 2.821 & 0.579 & 0.118 \\
\hline
\end{tabular}

Source: Authors' computations. Note: the Cholesky decomposition ordering is: LNREM, LNINF, GDPG, LNEXC, LNBM, and LNAGED.

In the short run (period 3), a shock or innovation to LNREM accounts for $91.16 \%$ variation of the fluctuation in LNREM (own shock). While the shock to LNINF causes $0.071 \%$ fluctuation in LNREM. The shock to GDPG on the other hand, causes $6.97 \%$ fluctuation in LNREM. Whereas, the shock to LNEXC causes a $0.85 \%$ fluctuation in LNREM a shock to LNBM accounts for $0.95 \%$ fluctuation in LNREM. Last but not least, a shock to LNAGED accounts for a $0.005 \%$ fluctuation in LNREM. In the long run, that is period 10, the shock to LNREM accounts for $88.55 \%$ variation of the fluctuation in LNREM (own shock). While the shock to LNINF causes $0.78 \%$ fluctuation in LNREM. The shock to GDPG on the other hand causes $7.716 \%$ fluctuation in LNREM. Whereas, the shock to LNEXC causes a $2.82 \%$ fluctuation in LNREM a shock to LNBM accounts for $0.58 \%$ fluctuation in LNREM. Last but not least, a shock to LNAGED accounts for a $0.12 \%$ fluctuation in LNREM.

\section{Conclusion and Recommendations}

The study sought to analyze select macroeconomic determinants of Remittances in Southern Africa. It was found that the only significant variables were GDP growth (changes/improvements in the home countries economic environment) and the exchange rate (costs of remitting). The results imply that, mere economic environmental conditions, previous remitting behavior, dependency and market sophistication do not influence the receiving of remittances in the selected Southern African countries. These results were not expected as it would be expected that a poor economic environment (which one would argue has been prevalent in the region) will see remittances flow into the economy as migrants try to support those left behind (of course this is also dependent on the fact that migrants left family behind). However, as changes/improvements in the economic environment are significant, the economic environment of the home country relative to the host country could play a vital role in the home countries as the changes reflect to an extent the economic environment. The potential for using remittances to encourage development in countries is tremendous, more so in the region since a lot of migration is within the region coupled with the relative substantial amount that remittances make up in comparison. 
To the gross domestic product (GDP) in some countries like Lesotho (approximately 30\%) there are various policy implications from the results. However, of importance is that as remittances have potential to aid economic growth and changes/improvements in the home countries economic environments do impact remittances, policy makers should figure out how remittances can be channeled for growth when the changes in their countries are not favourable more so as remittances do not respond to general home economic conditions. This further warranting the investigation of individual and demographic variables as opposed to merely macroeconomic variables (Huang \& Vargas-Silva, 2006; Coulibaly, 2009). Furthermore, it should be reiterated that reliable data on remittances is either incomplete or undervalued which leaves much to be desired to help understand the phenomenon. Informal remittances are large and unknown. A major effort will be necessary to improve data on remittances that will have to go beyond just gathering data.

It would require for instance, investigating the relationship between migration stock and remittance flows. Secondly, as aforementioned, the region has some of the highest costs of sending remittances. This reiterated by the finding of a positive and significant relationship between remittance inflows and the nominal exchange rate. These fees especially affect the poor. It is difficult to see why remittance fees should be so high, and why they should increase when the amount being transferred increases. Also, given that the average cost declines as remittances increase, there may be scope for policy measures that alleviate cash constraints and enable migrants to send larger amounts of funds (though less frequently), thereby saving on remittance costs. Last but not least, learning more about the best ways to capture and make use of remittances would require reconsidering how financial inflows are received in the respective countries. In addition, policymakers would need much more research on how to use remittances so they positively contribute to migrants' home communities and countries.

\section{References}

Adams, R. (2008). The Demographic, Economic and Financial Determinants of International Remittances in Developing Countries. Washington, DC: In World Bank Policy Research Working Paper 4583.

Baldé, Y. (2009). Migrants' Remittances and Economic Growth in Sub-Saharan Africa. World Development, (33), 1-23.

Bollard, A., McKenzie, D., Morten, M. \& Rapoport, H. (2009). Remittances and the Brain Brain Revisited: The Microdata Show that More Educated Migrants Remit More. Washington, DC: World Bank Policy Research Working Paper, 5113.

Boly, A., Coniglio, N. D., Prota, F. \& Seric, A. (2014). Diaspora Investments and Firm Export Performance in Selected Sub-Saharan African Countries. World Development, 59, 422-433.

Coulibaly, D. (2009). Macroeconomic Determinants of Migrants' Remittances: New Evidence from a panel VAR . Working paper. Documents de travail du Centre d'Economie de la Sorbonne, 1955- 611.

Crush, J. \& Frayne, B. (2007). The migration and development nexus in Southern Africa Introduction. Development Southern Africa, 24(1), 1-23.

Dorantes, C. A. (2014). The good and the bad in remittance flows: Remittances have the potential to lift up developing economies. The World Labor, 97.

Eyden, R. V., Sekyere, E. O. \& Kemegue, F. (2011). What drives remittance inflows to Sub-Saharan Africa? A dynamic panel approach. Pretoria: University of Pretoria.

Faini, R. (2007). Remittances and the Brain Drain: Do More Skilled Migrants Remit More? World Bank Economic Review, 21(2), 177-191.

Huang, P. \& Vargas-Silva, C. (2006). Macroeconomic Determinants of Workers' Remittances: Host versus Home country's Economic Conditions. Journal of International Trade Economic Development, 15(1), 81-99.

Lim, S. \& Mahbub-Morshed, A. K. (2015). International Migration, Migrant Stock, and Remittances: Reexamining the Motivations to Remit. The Quarterly Review of Economics and Finance, 57, 101-115.

Mohapatra, S. \& Ratha, D. (2011). Migrant Remittances in Africa: An overview (Chapter 1). In S. Mohapatra, \& D. Ratha, Remittance Markets in Africa (pp. 3-59). Washington, DC:: The World Bank.

Porter, A. (2017, April 5). Extreme poverty set to rise across Southern Africa. Retrieved from Institute for Security Studies: https://issafrica.org/iss-today/extreme-poverty-set-to-rise-across-southern-africa

Ratha, D. \& Plaza, S. (2011, September). Harnessing Diasporas: Africa can tap some of its millions of emigrants to help development efforts. Finance \& Development, 48-51. 


\section{Journal of Economics and Behavioral Studies (ISSN: 2220-6140)}

Vol. 11, No. 4, pp. 43-53, August 2019

Tabit, S. \& Moussir, C. E. (2016). Macroeconomic Determinants of Migrants' Remittances: Evidence from a Panel of Developing Countries. International Journal of Business and Social Research, 6(7), 1-11.

Watkins, K. \& Quattri, M. (2014). Lost in Intermediation: How excessive changes undermine the benefits of remittances for Africa. London.: Overseas Development Institute.

World Bank. (2016). Migration and Remittance Fact book, Third Edition. Washington, DC: The World Bank.

World Bank. (2016). Remittances Prices Worldwide. Retrieved from The World Bank: https://remittanceprices.worldbank.org/en

Yuni, D. N., Omeje, A. N. \& Asogwa, H. T. (2013). Determinants of Remittances: Panel Evidence from Selected Countries in Africa. Journal of Economics and Sustainable Development, 4(20), 52-57.

Zakari, A. Y. \& Nasiru, I. (2016). Modeling the Macroeconomic Determinants of Remittances: Evidence from West African Countries. Journal of Management Sciences, 14(1), 118-134. 